\title{
Considering 'Privacy' and Gender in Early Modern German-Speaking Countries
}

\author{
Heide Wunder
}

In order to study 'privacy' ('Privatheit') in early modern society, it is essential to understand and reflect the social setting of modern 'privacy'. ${ }^{1}$ Due to the digital revolution and the widespread use of social media, the common boundaries between public and private have been shifted by the exposure of the private, which threatens the integrity of the personal sphere..$^{2}$ The value of 'privacy' ('Privatheit') has thus been recognised and privacy has become a field of historical research in its own right. ${ }^{3}$ Before this development, its counterpart, 'the public' ('Öffentlichkeit'), had attracted scholarly historical interest because it is closely connected to 'res gestae' and political power. Unsurprisingly, neither the noun 'Privatheit' nor the adjective 'privat' are counted among relevant political and social terms in the German lexicon Geschichtliche Grundbegriffe. ${ }^{4}$ Both are only mentioned several times in the article on 'Öffentlichkeit', which confirms the asymmetrical construction of 'public-private', with 'the private' defined merely as the non-public. ${ }^{5}$ The investigation of the semantic field of 'public' and 'private' both in Latin and vernacular languages has brought to light a broad spectrum of usages, depending on the topic and its treatment in different types of written evidence over time. ${ }^{6}$ Gert Melville and Peter von

1 In writing this article, I am confronted with the problem of translating German terminology into English. 'Öffentlichkeit', for example, differs from 'the public'. Cf. von Moos P., "Der Begriff 'öffentlich' und 'privat' in der Geschichte und bei den Historikern”, Saeculum 49 (1998) 161-192, here 167-169; cf. Emmelius C. et al. (eds.), Offen und Verborgen. Vorstellungen und Praktiken des Öffentlichen und Privaten in Mittelalter und Früher Neuzeit (Göttingen: 2004). The Introduction by Fridrun Freise (9-32) gives a useful overview of research to date.

2 Von Moos P., "Das Öffentliche und das Private im Mittelalter. Für einen kontrollierten Anachronismus", in Melville G. - von Moos P. (eds.), Das Öffentliche und Private in der Vormoderne (Vienna - Cologne - Weimar: 1998) 3-83.

3 Roessler B., Der Wert der Privatheit (Frankfurt a.M.: 2001).

4 Brunner O. - Conze W. - Koselleck R. (eds.), Geschichtliche Grundbegriffe: Historisches Lexikon zur politisch-sozialen Sprache in Deutschland, vols. 1-8/2 (Stuttgart: 1972-1997).

5 Hölscher L., "Öffentlichkeit", in ibidem, vol. 4 (1978) 413-467.

6 Von Moos P., "Öffentlich" und "privat" im Mittelalter. Zu einem Problem der historischen Begriffsbildung (Heidelberg: 2004). 
Moos have discerned several dimensions of 'the public' and 'the private': (1) the social, political, and legal dimension, (2) religion, and (3) literature. ${ }^{7}$ These dimensions require the competences of different disciplines and, even more, their mutual acknowledgment.

The double term ('Begriffspaar') publicus-privatus goes back to the Roman Republic, when it marked the difference between persons who held public offices in contrast to the majority of people who acted in their own - private interest. The contempt of (manual) labour ('negotium') and the high value of leisure ('otium') was part of this concept. This explains why the vast field of economics - the household, agrarian and industrial production, commerce was excluded from 'the public' in Rome. Yet, Roman private law testifies to the enormous importance of economics for the Roman society. An officer was at the same time a private person, who as pater familias held patria potestas in his household, indicating that in Rome publicus-privatus was a complementary term and not an antithetical and asymmetrical construct as is the modern term. The latter developed its antithetical and asymmetrical character only in the eighteenth and nineteenth centuries - in the Age of Enlightenment and the French Revolution. The semantic changes from Roman times to the eighteenth century are partly hidden by the continuity of Latin terminology from antiquity to the Middle Ages, the early modern period, and the modern period notwithstanding the changing political and social contexts and their terminology in the vernacular languages. In German-speaking countries, the semantic field of 'offen'/'verborgen', 'geheim', 'heimlich' referred to what could be seen and observed by everybody as opposed to that which was hidden, secret, clandestine. It seems significant that the modern term 'Öffentlichkeit's developed from the adjectives 'offen/öffentlich', while no generalising term originated in 'verborgen, geheim, heimlich'. Instead, 'privat' from Latin privatus was introduced through the reception of Roman law in the sixteenth century and subsequently combined with nouns, as in 'Privatmann' and 'Privatperson'. ${ }^{9}$

The asymmetrical construction of public-private, which signalises the irrelevance of 'the private', and the seemingly diffuse semantic field may explain why historical research on 'the private' is rare. 'The private', however, has its place in the history of medieval and early modern religion and piety when it comes to analysing the individual's relationship with God. Here, pietism is the most

7 Melville G. - von Moos P. (eds.), Das Öffentliche und Private in der Vormoderne (Vienna Cologne - Weimar: 1998) XIV-XVI.

8 Habermas J., Strukturwandel der Öffentlichkeit (Frankfurt a.M.: 1990 [1962]).

9 Grimm J. - Grimm W., Deutsches Wörterbuch, vol. 13 (Leipzig: 1889) 2137-2140. See also Safley's contribution to this volume. 
prominent example. ${ }^{10}$ Rudolf Schlögl has linked public worship and private belief ('Öffentliche Gottesverehrung und privater Glaube') within the context of early modern church discipline. ${ }^{11} \mathrm{He}$ used the ample material of church courts concerning cases such as marriages, which he includes in 'Privatheit' following Niklas Luhmann's systems theory, ${ }^{12}$ but thereby neglecting the public aspects of marriage in the early modern period in favour of intimacy. In contrast, Mette Birkedal Bruun develops her approach to privacy by 'spotting notions of privacy' in the field of religion, but then raises the question: 'How do we, then, ferret out notions of privacy that are not called "privacy"?. This question asks for a new conceptual framework besides the linguistic approach and large-scale interdisciplinary cooperation. ${ }^{13}$

In the field of social history, gender as a category for analysing social inequality (Joan Scott) $)^{14}$ offers a promising approach suitable to elucidate and evaluate the imbalance of public-private. 'The private is public' was a central slogan of the Feminist movement in the 1970s and 1980s, when women protested against being normatively and socially allocated to the 'private sphere' of home and family. In Germany, women won the right to vote and to be elected after World War I. They gained equal rights to men (Gleichberechtigung) in both German states after World War II, yet in Western Germany they continued to be discriminated against in the educational system and in the labour market. In matrimony, women's work ('care') was not valued as work because it was unpaid. Women were not seen as competent to represent their children in court and their individual civil rights were not respected. Women's ambivalent experiences of the marital status did not fit the general notion of family constructed as a sphere of love and harmony, which needed no regulations. ${ }^{15}$

10 Brecht M. - Deppermann K. - Lehmann H. - Gäbler U. (eds.), Geschichte des Pietismus 1-4 (Göttingen: 1993-2004).

11 Schlögl R., "Öffentliche Gottesverehrung und privater Glaube in der frühen Neuzeit. Beobachtungen zur Bedeutung von Kirchenzucht und Frömmigkeit für die Abgrenzung privater Sozialräume", in Melville - von Moos (eds.), Das Öffentliche und Private 165-209.

12 Ibidem, 170-175; for a critique of Luhmann, cf. Rohmann G., "Kinship as Catalyst of Individuation in Sixteenth-Century German House-Books: A Reconsideration of Niklas Luhmann's Approach in Pre-Modern Individuality", in Arlinghaus F.-J. (ed.), Forms of Individuality and Literacy in the Medieval and Early Modern Periods (Turnhout: 2015) 199-232.

13 Bruun M.B., "Privacy in Early Modern Christianity and Beyond", Annali/Jahrbuch ISIG $44.2(2018) 33-54$.

14 Scott J.W., "'Gender': A Useful Category of Historical Analysis”, American Historical Review 91.5 (1986) 1053-1075; cf. Becker A., "Gender in the History of Early Modern Political Thought", Historical Journal 6o.4 (2017) 843-863.

15 Schwab D., "Familie", in Brunner - Conze - Koselleck, Geschichtliche Grundbegriffe, vol. 2 (1975) 253-301, here 286-289. 
Instead, family was the sphere of 'private domination' ('private Herrschaft') of men as husbands and heads of households/families, while the agency of married women was restricted until 1976/1979. ${ }^{16}$ 'Private Herrschaft' was regarded as characteristic of premodern domination and therefore family was excluded from Hans-Ulrich Wehler's Deutsche Gesellschaftsgeschichte. ${ }^{17}$ Consequently, the antithetical construction of public-private based on the exercise of legitimate power as a distinctive criterion cannot be maintained because this power was not reserved for public authorities only but it was also held by married men with respect to family. ${ }^{18}$ Thus, the essential parts of the private sphere matrimony and family - were defined by power relations and legitimated by matrimonial law, private law, and family law. Although not every man and every woman were married, matrimony was central in the normative (hierarchical) regulation of gender relations.

In the 1970s and 1980s, gender discourse in philosophy, political theory, and theology seemed to prove the long continuity of gender hierarchy and women's allocation to the domestic sphere since antiquity. Mainstream German historiography mirrored these ideas following especially the gender concepts of the Enlightenment, which had based gender differences on 'nature'. As a consequence, women, gender relations, and family were regarded as part of the human condition ('anthropologische Konstante') without history, being rather the object of 'Kulturgeschichte.' 'Political women' - such as successful queens - were constructed as 'exceptions to their sex'. In reaction to these perceptions, Women's History, prompted by the Women's Movement, attempted to restore women to history, which in those years meant restoring them to the public sphere. This strategy was successful in rewriting the history of the early modern period to some extent:19 matrimony and household were established as public institutions assuring a status of authority for wives and widows, and women's participation in dynastic rule was acknowledged. ${ }^{20}$ Recent research in the history of political ideas has confirmed these early findings of social and

16 Schwab D., "Gleichberechtigung und Familienrecht im 20. Jahrhundert", in Gerhard U. (ed.), Frauen in der Geschichte des Rechts. Von der Frühen Neuzeit bis zur Gegenwart (Munich: 1997) 790-827.

17 Wehler H.U., Deutsche Gesellschaftsgeschichte (Munich: 1987-2008).

18 This was also true for factory-discipline.

19 Wiesner M.E., Women and Gender in Early Modern Europe (Cambridge: 1993).

20 Wunder H., "Einleitung. Dynastie und Herrschaftssicherung in der Frühen Neuzeit: Geschlechter und Geschlecht", in Wunder H. (ed.), Dynastie und Herrschaftssicherung in der Frühen Neuzeit. Geschlechter und Geschlecht (Berlin: 2002) 9-27. 
legal historians by analysing Pseudo-Aristotelian concepts of household and marriage as they were discussed in the fifteenth and sixteenth centuries. ${ }^{21}$

These revisions of anachronistic concepts of the early modern 'domestic sphere' dealt with 'private domination', its physical spaces, interpersonal relations, and legal devices (private law), but also with the affirmative and emancipatory role of religion in gender relations. Further aspects of what we are accustomed to associate with 'the private' - its individual, emotional, and imaginative dimensions - were mainly the subjects of literary and art historians until Philippe Ariès published his volume of Histoire de la vie privée. ${ }^{22}$ The latter, however, is explicitly inspired by Ariès's idea of 'socialité', not by reflections about 'the private' and privacy.

In my attempt to explore aspects of 'privacy' and gender in the early modern period, it is imperative to explain first the modern notions of privacy and their origins in the eighteenth and nineteenth centuries with the focus on gender relations in family and home. Secondly, I shall compare the modern concept of family and home with the early modern household (oeconomia) and its model of partly shared authority of the married couple in order to detect spaces of individual agency. Thirdly, further aspects of individual freedom for shaping marriage (love) and other associations (friendship) will be investigated.

\section{$1 \quad$ Notions of Modern Privacy: Family and Home}

Today, 'privacy' is a physical, mental, intellectual, and emotional space protected by law as part of human rights granted to every human being by the 1948 Universal Declaration of Human Rights. ${ }^{23}$ Article 12 states that 'No one shall be subjected to arbitrary interference with his privacy, family, home or correspondence, nor to attacks upon his honour and reputation. Everyone has the right to the protection of the law against such interference or attacks'. In the articles 13 to 19 the notion of 'privacy' is specified in more detail: integrity of the body, freedom of thought, speech, and religion, freedom to marry, freedom of movement, and property rights. 'Privacy' thus covers a wide spectrum of individual

21 Becker A., "Der Haushalt in der politischen Theorie der Frühen Neuzeit", in Eibach J. Schmidt-Voges I. (eds.), Das Haus in der Geschichte Europas. Ein Handbuch (Oldenburg: 2015) 667-684.

22 Ariès Ph. - Duby G. - Chartier R. (eds.), Histoire de la vie privée, vol. 3: De la Renaissance aux Lumières (Paris: 1986).

23 Universal Declaration of Human Rights, Article 12, on United Nations website. Online edition. https://www.un.org/en/universal-declaration-human-rights, accessed on 15 November 2020 . 
agency ('freedom') in the ways the individual develops his/her personality and forms his/her relationships with other individuals.

As the title and the first article indicate, the Universal Declaration of Human Rights adopts the tradition of the 1789 Déclaration des Droits de l'Homme et $d u$ Citoyen, which became the social and political programme of the French Revolution. But while Human Rights in 1948 were granted to every individual human being without respect to sex, 'Human and civil rights' of 1789 only addressed men in their political role as citoyen, while women, according to the gender concepts of the Enlightenment, were 'by nature' allocated to the domestic sphere without any agency in the political sphere. So what at first sight seems to be a universal concept of human rights turns out to be heavily gendered and not in accordance with the first article of the Déclaration, which asserts that 'all human beings are born free and equal in dignity and rights.' ${ }^{24}$ While 'born free' referred to both men and women, following early notions of the Enlightenment, the same cannot be said about 'equal in dignity and rights', which took up Rousseau's notion of 'natural' differences between the sexes. This was due to the fact that patria potestas, abolished as part of the old feudal system in the early years of the French Revolution, was reintroduced by the Code civil of 1804. Olympe de Gouges protested in vain against women's exclusion from human rights and citizenship by claiming equal rights with men in her 1791 Déclaration des droits de la Femme et de la Citoyenne. And by adding a form of a marriage contract under these new conditions she demonstrated the consequences: the marriage contract would no longer imply the bride's subjection to male authority, but marriage would be constituted as a union of two free and equal partners who consented to it freely, i.e. as a true 'contrat social'.

As a propertied tax payer, the citoyen participated in the exercise of legitimate political power in the nation state. At the same time, his status as père de famille ensured him private domination (la puissance maritale et paternelle) over his wife, children, and dependent persons in his family. 'By nature', women had no agency in the public sphere. According to law, a married woman was under total control of her husband, who was entitled to control her property, correspondence, friends, and mobility in order to ensure her sexual fidelity.

24 Déclaration des Droits de l'Homme et du Citoyen, Article 1: 'Les hommes naissent et demeurent libres et égaux en droits. Les distinctions sociales ne peuvent être fondées que sur l'utilité commune'. Article 2: 'Le but de toute association politique est la conservation des droits naturels et imprescriptibles de l'homme. Ces droits sont la liberté, la propriété, la sûreté et la résistance à l'oppression'. Taken from Légifrance. Le service public de la diffusion du droit. Online edition. https://www.legifrance.gouv.fr/contenu/menu/droit -national-en-vigueur/constitution/declaration-des-droits-de-l-homme-et-du-citoyen -de-1789, accessed on 15 November 2020. 
The wife's individual rights were not protected - not even the integrity of her body. ${ }^{25}$ Her status was defined by the family as the little fatherland mirroring the 'grande nation'. This process was accompanied by the dissociation of home and work, which transferred wage labour and professional work to offices and factories, leaving unpaid housework and childcare to the housewife. Thus, the family was the citoyen's private sphere protected from the intervention by the state and co-citoyens, a place where the individual was supposed to develop freely as an autonomous personality in order to act as a responsible citizen ('mündiger Bürger'). Married women were enclosed in their husbands' private sphere without any legal agency of their own and without respected individual privacy, except piety. ${ }^{26}$

'Private domination' in the family was first established by the Code civil, but it was more or less characteristic of all private law systems in Western Europe. It is telling that 'private domination' was intimately connected with the concept of romantic love - the epitome of intimacy and 'the private' - as a precondition of marriage.

\section{The Early Modern Household}

Sociologists have characterised 'private domination' in the nineteenth-century family as 'secondary bourgeois patriarchalism, ${ }^{27}$ suggesting the continuity of early modern patriarchalism. Indeed, patria potestas existed in the early modern period, but it was neither situated in the 'family' in the modern sense of the nuclear family nor was it the centre of 'private domination'. Rather, it was just one element of authority in the 'household' (oeconomia). The difference is best expressed by comparing the relation between family and household and the larger political unit: while the family as 'le petit patrie' mirrored the fatherland of the nation, the household in early modern politic philosophy was regarded as the origin and model of good government. ${ }^{28}$ In the German context this

25 Vogel U., "Gleichheit und Herrschaft in der ehelichen Vertragsgesellschaft - Widersprüche der Aufklärung", in Gerhard U. (ed.), Frauen in der Geschichte des Rechts. Von der Frühen Neuzeit bis zur Gegenwart (Munich: 1997) 265-292.

26 Gerhard U., "Civil Law and Gender in Nineteenth-Century Europe", Clio. Women, Gender, History 43.1 (2016) 250-273.

27 König R., "Familie und Autorität. Der deutsche Vater im Jahre 1955", in König R. (ed.), Materialien zur Soziologie der Familie (Cologne: 1974) 211-230, here 217-219.

28 Becker, "Der Haushalt in der politischen Theorie der Frühen Neuzeit" 667-684; cf. Dürr R., Mägde in der Stadt. Das Beispiel Schwäbisch Hall in der Frühen Neuzeit (Frankfurt - New York: 1995) 17. 
meant that the territorial prince (Landesherr) was regarded as 'Landesvater' and his consort as 'Landesmutter', both of whom took care of their court as their household but also of their subjects all over the country.

The model household comprised the married couple, their children, and servants. As the house was not only a piece of property and a precondition to be accepted as a burgher or member of a rural community, but also - besides land - the most important site of household and market production and of retail, children as well as maids, farm labourers, apprentices, and journeymen working and living in the household fell under the patria potestas of the paterfamilias. He had to care for them and represent them in court. The second aspect of 'private domination' concerns the married couple as the household's centre. Bride and bridegroom promised to share good and bad times. Still, the husband was 'das Haupt der Frau', who represented her in court and administrated her property (cura sexu), while the wife was obliged to obey him and to contribute to the household with her work. He had to protect her, but was also entitled to punish her 'modestly' in case of disobedience. At the same time, the married couple shared authority over their children and as paterfamilias and materfamilias they were held responsible by the local authorities to keep peace and order inside the house, as prescribed in the Policeyordnungen. Shared conjugal authority is expressed by the term 'the ruling couple' ('das regierende Paar'), a term used not only for the prince and his consort, but also for peasant couples. A notion of equality of husband and wife can be detected even in the traditional division of labour between them, which was merely functional and could be changed when necessary: the husband could delegate his authority to his wife in cases of illness or absence, and the widow was both mother and father of underage children.

The paterfamilias represented the household in the local community, whereas the wife in her church pew represented the 'honour of the house' (Hausehre) when the community assembled. In protestant territorial states and imperial cities, the wife's death was commemorated just as her husband's in 'volkreicher Versammlung' ('populous community') by a funeral sermon including her curriculum vitae, which presented her as a good Christian daughter, wife, and materfamilias.

The household provided safety to the domestic group by the exercise of 'private domination' of master and mistress. Their property, the house, was a physical space (building), offering shelter and protection from outside intruders and assaults. Nobody was allowed to peep through the windows or overhear what was going on inside the house. Boundaries were eaves and thresholds. The same was true of the members of the household: nobody - especially servants - was allowed to spread information concerning the household that 
might weaken the household's position in the neighbourhood or community. ${ }^{29}$ Yet, in cases of emergency, paterfamilias and materfamilias had to defend their house in cooperation with their neighbours and the people living with them. ${ }^{30}$ Private domination ('private Herrschaft') seems to have been instrumental in controlling bodies and social interactions inside the house, but did not provide separate 'private' spaces for its individual members. Rather, moveable property such as one's own bed or objects that could be locked, such as the chest with the wife's dowry and the maids' chests containing their personal belongings, were regarded as 'private' and as an extended space of one's personality.

Despite the transformation of political ideas via the reception of PseudoAristotelian oeconomia in the fifteenth century, religion and church law continued to play a central role in social life. On the one hand, the Church established religious legitimation of gender hierarchy by recourse to Genesis, and had succeeded in attaining control over marriage by declaring it as a sacrament in the twelfth century. On the other hand, the laity, the 'privati' by church law, ${ }^{31}$ began to develop practices of personal piety outside the church, preferably 'at home', by using devotional pictures and altars, prayer books, and the Bible in the vernacular. These practices created an inner space of meditation and self-reflection, especially for women, who were excluded from church offices. The Reformation took up popular piety and linked it to Church reform: the divide between priesthood and laity was abolished, all baptised were equal in relation to Christ, and marriage lost its sacramental status. The household was defined as 'oeconomia christiana,'32 where paterfamilias and materfamilias were held to 'christianise daily life' ('den Glauben ins Leben ziehen'). ${ }^{33}$ Domestic religious instruction and praying was common to all members of the household ('Hauskirche'), but in those households that had enough servants for household work and childcare, spare time and temporal command of space for private worship was conceded to the mistress of the house. Many funeral sermons for married women mention that they retired to a separate room to pray, where nobody could disturb their devotional practice. ${ }^{34}$

29 These aspects are dealt with in local customs. See, for example, Kramer K.S., Grundriss einer Rechtlichen Volkskunde (Göttingen: 1974).

30 Institut für evangelisches Kirchenrecht der EKD (ed.), Landgrafschaft bis 1582. Die gemeinsamen Ordnungen: 1, Die Landgrafschaft Hessen bis zum Tode Philipps des Großmütigen, vol. 8: Hessen I (Göttingen: 1965) 41.

31 Von Moos, "Öffentlich" und "privat" im Mittelalter 37.

$3^{2}$ Menius Justus, Oeconomia Christiana, das ist, von christlicher Haushaltung (Wittenberg, Hans Lufft: 1529).

33 Wunder H., He Is the Sun, She Is the Moon: Women in Early Modern Germany, trans. T. Dunlap (Cambridge, MA: 1998).

Bruun, "Privacy" 41. 
Freedom of conscience was another result of the Reformation and the emergence of several confessions by which established forms of domination could be restricted. As the right of 'cujus regio ejus religio' (1555) did not allow forcing the subjects of a territory to convert to the prince's confession, but granted the right to emigrate, the husband could not force his confession on his wife nor the bridegroom on his bride in mixed marriages. Often free exercise of her confession was granted to the bride even in the marriage contract, but this related only to her as a 'private person' ('Privatperson'), not to the children. ${ }^{35}$ Nevertheless, freedom of conscience encroached upon the husband's imperium conjugale and was judged to endanger conjugal peace in the negotiations of aristocratic marriage contracts. ${ }^{36}$

'Gewissensfreiheit' limited the husband's imperium maritalis, and practices of piety could interrupt household duties of the mistress of the household, thus creating a spiritual, temporal, and physical space for her, dedicated to a conversation with God. Literary sources and autobiographies offer further insights into individual and intimate aspects of associations such as marriage (love) and household (friendship), which might be qualified as private in the modern sense.

\subsection{Love and Matrimony: Burkart Zink's Narrative of His First Marriage}

Burkart Zink (1396-1474/75), citizen of the imperial town of Augsburg, married at the age of 24. He was a servant in a rich merchant's business and his bride, Elisabeth Störklerin, was a maid servant in the merchant's household. Burkart and Elisabeth had decided to marry, and they took each other in 'amicable concord' (gute freuntschaft). The bride's mother, a (poor) widow, approved of their union, for she provided her daughter with a small dowry. Thus, the young couple observed a number of formalities for the conclusion of a valid marriage: the mutual consent of the betrothed and the parental consent. Zink had no living parents, siblings, or close kin who would have any say in the matter. He does not even mention any wedding ceremonies. The public informed of this marriage was doubtless very small for the event took the young couple's employer by surprise. He was annoyed that Zink, who lived as a dependent in his

35 Kepsch S., Dynastie und Konfession: Konfessionsverschiedene Ehen in den Grafenhäusern Nassau, Solms und Isenburg-Büdingen 1580-1648 (Marburg: 2021).

36 Ibidem. 
household, had not asked his advice and he dismissed both Zink and his wife without notice. Zink had not anticipated this outcome, believing himself dear to his master since he had proven himself a good servant. Except for Elisabeth's small dowry, the young couple were virtually penniless. Zink had only his clothes and a little money. The couple lived in rented lodgings and had to earn their keep with wage labour. Working tirelessly, they soon succeeded and prospered, a fact that Zink attributed to the symbolic capital of honour and virtuousness' ('er und frumkait') ${ }^{37}$ that he and Elisabeth had brought together, a dowry he estimated to be more valuable than property or money.

Obviously, this marriage was a love match. What were the conditions that allowed transferring a love affair into a legal marriage? Zink's marriage was a clandestine marriage which by canonical law required only the couple's consent, while in town laws marriage was treated differently: the couple needed the parents' consent and there had to be witnesses to their betrothal if they wanted to get the property that was exchanged between their parents. But in Zink's case no family property existed. In other words, as long as a marriage was not accompanied by the transfer of property, young people earning their own living were free to make their own choices. This type of marriage without a written marriage pact only came to scholarly attention by being contested in court. Marriage pacts are only available for propertied people, that is, a social minority.

Nevertheless, affection as the foundation of matrimony is also documented for the propertied classes. Since the fifteenth century, portraits of future marriage partners living in different towns were exchanged and when the courtship was successful, they were combined to represent the married couple. In the sixteenth century, this trend to reveal personal affection is also found in family portraits, which show both the conjugal pair and the loving relation to their children as parents. ${ }^{38}$ At the beginning of the fifteenth century, Burkart Zink indirectly expressed his affection for his eldest daughter, Anna, by describing how everybody wanted to caress her. ${ }^{39}$ Zink does not tell anything about Elisabeth's love for her ten children, but 'Mutterliebe' was proverbial. When the future humanist Johannes Butzbach (about 1500) left his home town to become a 'fahrender Schüler', his mother accompanied him for a while. Before they finally said farewell, she secretly gave him some money, called 'mother's

Historische Commission bei der Königlichen Academie der Wissenschaften (ed.), Die Chroniken der schwäbischen Städte. Augsburg, vol. 2, Chronik des Burkhard Zink (Leipzig: 1866) $1-33$.

38 Hinz B., "Studien zur Geschichte des Ehepaarbildes", Marburger Jahrbuch für Kunstwissenschaft 19 (1974) 139-218.

Historische Commission, Chroniken 135. 
penny' ('Mutterpfennig') ${ }^{40}$ In books on education, though, parents were reproached for indulging their children and admonished to discipline them more strictly or let them be educated by strangers. ${ }^{41}$

\subsection{Friendship: 'Von guten und bösen Nachbarn' (1556)}

My second example concerns the (re)formation of an early modern urban household in the context of traditional relations of marriage, kinship ('Freundschaft'), and neighbourhood by true personal friendship. In his 1556 'Histori' 'Von guten und bösen Nachbarn,'42 Jörg Wickram (1505-1562), a citizen of Colmar and since 1554 town secretary of Burkheim am Kaiserstuhl, tells three interrelated stories of friendship..$^{43}$ Having lost most of his children and experienced neighbourly malice, the merchant Robertus leaves his home town of Antwerp for Portugal. There he is without kin, 'mutterseelenallein', but by accident meets another foreign merchant, Richardus. They become friends and Robertus cares for Richardus during his illness. Unwilling to leave him, Robertus takes him into his house and makes him his business partner. Finally, Richardus marries Robertus's daughter. Richardus as a foreigner has enemies in Lisbon, who try to murder him, but he is saved by the young goldsmith Lazarus. They become friends and live in neighbouring houses. This friendship is strengthened even more after Richardus liberates Lazarus from the hands of slave traders. After both marry, they decide to make a door in the wall separating their houses so that their wives might communicate whenever they want to without having to leave the house and cross the street, where they could be confronted with malicious neighbours. True friendship, then, is identical with good neighbourhood. The two friends went even further: they planned to perpetuate their friendship by wedding their children, who - of course - had already fallen in love with one another, unnoticed by their parents. But before the wedding, young Lazarus has to leave home, travel in foreign countries, and experience loneliness and the worth of true friendship.

True personal friendship, then, was a precondition of good neighbourhood. The notion of good neighbourhood offers a frame of close social interaction which, however, has to be renewed in every generation by the experience

\footnotetext{
$40 \quad$ Butzbach Johannes, Odeporicon. Wanderbüchlein (Zurich: 1993) 42-43.

41 Ozment S.E., When Fathers Ruled: Family Life in Reformation Europe (Cambridge, MA: 1983) 133-134.

42 'Nachbarn' signified both the next-door neighbour and a member of a town or village community.

43 The narration partly follows Müller J.D., "Frühbürgerliche Privatheit und altständische Gemeinschaft. Jörg Wickrams Historie von Guten und Bösen Nachbarn", Internationales Archiv für Sozialgeschichte der deutschen Literatur 5 (1980) 1-32.
} 
of bad neighbourhood and lack of neighbourhood in a foreign country. The 'medicine' is to make one's proven personal friend one's neighbour and even a 'friend' (close kin) by intermarriage. In this concept, traditional communality and bonds of kinship are saved by the intimate personal association between true friends, but, conversely, it may suggest that true friendship is not possible when surrounded by bad neighbours and that one's personal resources can only be developed 'in exile'. In any case, both interpretations show the expansion of the self in friendship and the attempt to create a spatial sphere, a territory for intense personal emotions, an island of friendship which might be called 'private'.

When looked at from the gender perspective, it appears that true friendship was a friendship between men and finally served to confirm the position of the paterfamilias. Their domestic isle of friendship meant 'splendid isolation' from the outside world for their wives, who were protected, but did not have the possibility of free association with other women. For women, close female kin were still the only 'friends'. Inside the house there were separate rooms, which, however, were not private spaces of individuals. Richardus's daughter had a room of her own, but in the morning its windows and the door were open, so the father could overhear his daughter talking to herself about her being in love with the neighbour's son. Both her parents heavily reproached her for not having communicated to them this news of great import for her future life and for keeping her love secret. Her separate room might have protected her from being watched permanently by servants, but did not protect her from parental control. Nor was she allowed the right to secrecy in her personal affairs because her virtuousness and marriage were no 'private matters' in the eyes of early modern well-to-do merchants.

\section{Concluding Remarks}

Choosing 'gender' as an analytical category in my attempt to detect aspects of 'privacy' in the early modern period, the focus is on 'private domination' ('private Herrschaft') in institutionalised gender relations (marriage, household, and family). In this context, 'private' refers to the sphere of 'private persons' in contrast to persons holding an office in the public sphere. Legally, 'private domination' was based on imperium conjugale over the consort and on patria potestas over the children and dependent persons in the household, who were located in the house (building), which provided shelter and protection, but simultaneously constituted 'private property' and the precondition to be accepted as a member of the urban or rural community. In consequence, the 
'private person' was the role model for a married man and householder, who had agency in personal, economic, and communal (political) matters. At the same time, his wife was the mistress of the house in charge of the household economy and she shared authority with her husband.

This concept of 'private domination' which combined control of persons and domestic spaces left no room for 'privacy' in the sense of legitimate individual agency. Instead, secrecy and dissimulation formed alliances between the members of the nuclear family and servants as well as alliances of servants against master and mistress, proving the power ('Macht') of the dominated (Michel Foucault). ${ }^{44}$ This explains the long tradition of 'the cunning wife' in literature and art $^{45}$ as well as the discourse about disloyal servants. ${ }^{46}$ The fact that personal relations not guided by material interest, i.e. 'true friendship', could only be developed outside the household and that love could become the foundation of marriage when parental authority and the transfer of property were absent only serve to affirm the validity of 'private domination'. Women's individual agency essentially depended on reducing the husband's imperium conjugale, a process that began in the age of Reformation by establishing freedom of conscience for all Christians and ensuring (limited) space and time for the self.

\section{Bibliography}

Ariès Ph. - Duby G. - Chartier R. (eds.), Histoire de la vie privée, vol. 3: De la Renaissance aux Lumieres (Paris: 1986).

Becker A., "Gender in the History of Early Modern Political Thought", HistoricalJournal 60.4 (2017) 843-863.

Becker A., "Der Haushalt in der politischen Theorie der Frühen Neuzeit", in Eibach J. - Schmidt-Voges I. (eds.) in Verbindung mit Derix S. - Hahn Ph. -

44 Foucault M., "Subject and Power", in Dreyfus H. - Rabinov P. (eds.), Michel Foucault: Beyond Structuralism and Hermeneutics (Chicago: 1982) 208-226; cf. Honegger C. Heintz B. (eds.), Listen der Ohnmacht. Zur Sozialgeschichte weiblicher Widerstandsformen (Frankfurt a.M.: 1981).

45 Horn K., "List", in Brednich R.W. et al., Enzyklopädie des Märchens. Handwörterbuch zur historischen und vergleichenden Erzählforschung, vol. 8 (Berlin - New York: 1996) 10971104; Seemann E.A., "Weiberregiment, Weibermacht, Weiberlisten", in Olbrich H. (ed.), Lexikon der Kunst, vol. 7 (Leipzig: 1994) 739-740; Smith S.I., "The Power of Women Topos on a Fourteenth-Century Embroidery", Viator 21 (1990) 203-227. 
Harding E. - Lanzinger M. (eds.), Das Haus in der Geschichte Europas. Ein Handbuch (Berlin - Munich - Boston: 2015) 667-684.

Bruun M.B., "Privacy in Early Modern Christianity and Beyond", Annali/Jahrbuch ISIG $44.2(2018) 33-54$.

Brecht M. - Deppermann K. - Lehmann H. - Gäbler U. (eds.), Geschichte des Pietismus, 4 vols. (Göttingen: 1993-2004).

Brunner O. - Conze W. - Koselleck R. (eds.), Geschichtliche Grundbegriffe: Historisches Lexikon zur politisch-sozialen Sprache in Deutschland, vols. 1-8/2 (Stuttgart: 1972-1997).

Butzbach Johannes, Odeporicon. Wanderbüchlein (Zurich: 1993).

Dürr R., Mägde in der Stadt. Das Beispiel Schwäbisch Hall in der Frühen Neuzeit (Frankfurt - New York: 1995).

Emmelius C. et al. (eds.), Offen und Verborgen. Vorstellungen und Praktiken des Öffentlichen und Privaten in Mittelalter und Früher Neuzeit (Göttingen: 2004).

Foucault M., "Subject and Power", in Dreyfus H. - Rabinov P. (eds.), Michel Foucault: Beyond Structuralism and Hermeneutic (Chicago: 1982) 208-226.

Gerhard U., "Civil and Gender Law in Europe in the 19th Century", Clio. Women, Gender, History 43.1 (2016) 250-273.

Grimm J. - Grimm W., Deutsches Wörterbuch, vol. 13 (Leipzig: 1889).

Habermas J., Strukturwandel der Öffentlichkeit (Frankfurt a.M.: 1962).

Hinz B., "Studien zur Geschichte des Ehepaarbildes", Marburger Jahrbuch für Kunstwissenschaft 19 (1974) 139-218.

Historische Commission bei der Königlichen Academie der Wissenschaften (ed.), Die Chroniken der schwäbischen Städte. Augsburg, vol. 2, Chronik des Burkhard Zink (Leipzig: 1866).

Honegger C. - Heintz B. (eds.), Listen der Ohnmacht. Zur Sozialgeschichte weiblicher Widerstandsformen (Frankfurt a.M.: 1981).

Horn K., "List", in Brednich R.W. et al, Enzyklopädie des Märchens. Handwörterbuch zur historischen und vergleichenden Erzählforschung, vol. 8 (Berlin - New York: 1996) 1097-1104.

Kepsch S., Dynastie und Konfession: Konfessionsverschiedene Ehen in den Grafenhäusern Nassau, Solms und Isenburg-Büdingen 1580-1648 (Marburg: 2021).

König R., "Familie und Autorität. Der deutsche Vater im Jahre 1955”, in König R. (ed.), Materialien zur Soziologie der Familie (Cologne: 1974) 211-230.

Kramer K.S., Grundriss einer Rechtlichen Volkskunde (Göttingen: 1974).

Melvillle G. - von Moos P. (eds.), Das Öffentliche und Private in der Vormoderne (Vienna - Cologne - Weimar: 1998).

Menius Justus, Oeconomia Christiana, das ist, von christlicher Haushaltung (Wittenberg, Hans Lufft: 1529). 
Müller J.D., "Frühbürgerliche Privatheit und altständische Gemeinschaft. Jörg Wickrams Historie von Guten und Bösen Nachbarn", Internationales Archiv für Sozialgeschichte der deutschen Literatur 5 (1980) 1-32.

Roessler B., Der Wert der Privatheit (Frankfurt a.M.: 2001).

Rohmann G., "Catalyst of Individuation in Sixteenth-Century German House-Books: A Reconsideration of Niklas Luhmann's Approach in Pre-Modern individuality", in Arlinghaus F.-J. (ed.), Forms of Individuality and Literacy in the Medieval and Early Modern Periods (Turnhout: 2015) 199-232.

Schlögl R., "Öffentliche Gottesverehrung und privater Glaube in der frühen Neuzeit. Beobachtungen zur Bedeutung von Kirchenzucht und Frömmigkeit für die Abgrenzung privater Sozialräume", in Melville G. - von Moos P. (eds.), Das Öffentliche und Private in der Vormoderne (Cologne - Weimar - Vienna: 1998) 165-209.

Schwab D., "Gleichberechtigung und Familienrecht im 20. Jahrhundert", in Gerhard U. (ed.), Frauen in der Geschichte des Rechts. Von der Frühen Neuzeit bis zur Gegenwart (Munich: 1997) 790-827.

Scott J.W., “Gender': A Useful Category of Historical Analysis", American Historical Review 91.5 (1986) 1053-1075.

Seemann E.A., "Weiberregiment, Weibermacht, Weiberlisten", in Olbrich H. (ed.), Lexikon der Kunst, vol. 7 (Leipzig: 1994) 739-740.

Smith S.I., "The Power of Women Topos on a 14th-Century Embroidery", Viator 21 (1990) 203-227.

Vogel U., "Gleichheit und Herrschaft in der ehelichen VertragsgesellschaftWidersprüche der Aufklärung", in Gerhard U. (ed.), Frauen in der Geschichte des Rechts. Von der Frühen Neuzeit bis zur Gegenwart (Munich: 1997) 265-292.

Von Moos P., "Der Begriff 'öffentlich' und 'privat' in der Geschichte und bei den Historikern", Saeculum 49 (1998) 161-192.

Von Moos P., "Das Öffentliche und das Private im Mittelalter. Für einen kontrollierten Anachronismus", in Melvillle G. - von Moos P. (eds.), Das Öffentliche und Private in der Vormoderne (Vienna - Cologne - Weimar: 1998) 3-83.

Von Moos P., "Öffentlich" und "privat" im Mittelalter. Zu einem Problem der historischen Begriffsbildung (Heidelberg: 2004).

Wehler H.U., Deutsche Gesellschaftsgeschichte (Munich: 1987-2008).

Wiesner M.E., Women and Gender in Early Modern Europe (Cambridge: 1993).

Wunder H., He Is the Sun, She Is the Moon. Women in Early Modern Germany (Cambridge, Mass.: 1998).

Wunder H., "Einleitung. Dynastie und Herrschaftssicherung in der Frühen Neuzeit: Geschlechter und Geschlecht", in: Wunder H. (ed.), Dynastie und Herrschaftssicherung in der Frühen Neuzeit. Geschlechter und Geschlecht (Berlin: 2002) 9-27. 